\title{
3 The political economy of coal in Bulgaria
}

\author{
The silent phase-out
}

\author{
Toma Pavlov
}

\section{Introduction}

To achieve the European Union's (EU) ambitious goal of carbon neutrality by 2050, Bulgaria will have to replace over a third of its power generation capacities. Coal-fired power plants provide on average $40 \%$ of the electricity generation (up to $60 \%$ during cold winter months) and have been essential providers of baseload energy for over five decades (EWRC 2019). With over 15000 jobs in mining and power plants and approximately twice as many indirect jobs, Bulgaria is expected to be one of the most impacted EU Member States by a phase-out of coal (Vladimirov, Galev, and Primova 2020). Bulgaria's National Energy and Climate Plan (NECP) for 2021-2030 envisions the "full use of the existing potential of indigenous coal, which is sufficient to generate electricity for the next 60 years" (MoE and MoEW 2020, p. 25). At the same time, the increase in the price of allowances under the EU's emissions trading scheme (ETS), coupled with the underlying indebtedness and inefficiency of the coal industry, has resulted in soaring financial losses for power plants and mines. Domestic political decision makers have nonetheless demonstrated a willingness to go to extraordinary lengths in order to keep the industry afloat, even if some of its support is likely to be deemed a form of illegal state aid by the European Commission (Peeva 2020).

To better understand the continuous resistance to a shift away from coal, the present study investigates the political economy drivers of the coal regime in Bulgaria. Notwithstanding the lack of political willingness, the country has fully subscribed to the EU's carbon-neutrality goal (European Council 2019). Despite the favorable geographical conditions and the falling technological costs, Bulgaria has been reluctant in the introduction of renewables and has previously imposed numerous regulatory and administrative barriers after a rapid "boom and bust" deployment period (Couture, Pavlov, and Stoyanova 2021).The contradictory policy stances make Bulgaria a particularly interesting case study that requires looking beyond the techno-economic and innovation perspectives of energy transitions and analysing the role of sociopolitical factors.

The survey of literature shows that Bulgaria's coal regime has remained largely understudied. While there have been a few case studies on the 
Bulgarian energy sector, their focus has mainly been the mismanaged policy on renewables during the 2009-2012 period (Hiteva and Maltby 2017; Andreas, Burns, and Touza 2018; Ivanov 2019). For example, Ivanov (2019) stresses the negative role of state capture in the energy sector during the rapid introduction of renewables, where support schemes went to politically connected entrepreneurs. Outside the academic literature, various policy reports by the Center for the Study of Democracy in Bulgaria have shed light on key governance issues in the energy sector throughout the years (CSD 2017, 2018; Stefanov et al.2014), including providing an assessment of the draft version of Bulgaria's NECP (Vladimirov, Galev, and Stefanov 2019). In a country report on low-carbon transition, Heilmann, Reitzenstein, and Ámon (2019) analyze three categories of Bulgaria's political economy - national conditions, political system, and external projection. Based on a mapping of threats and opportunities, the authors argue that most political economy factors stand in opposition to a transition to a low-carbon economy. The present study contributes to the developing literature on political economy drivers in energy transitions (Brauers and Oei 2019; Leipprand and Flachsland 2018; Lockwood, Mitchell, and Hoggett 2019). While other European countries, including Germany, Poland, Spain, and the United Kingdom, have already been studied (Brauers, Herpich, and Oei 2018; Rentier, Lelieveldt, and Kramer 2019), this is the first case study to provide an in-depth analysis on the political economy of coal in Bulgaria.

\section{Methodology}

The study adopts the political economy framework by Jakob et al. (2020) covered in Chapter 1 that comprises a three-step approach: (1) identifying key actors with stakes in the policymaking process, (2) mapping of the actors' underlying objectives, and (3) assessing relevant contextual factors that influence policymaking. The framework is operationalized in two steps. First, a design of an interview guideline used in 20 semi-structured expert interviews with actors from government, business, civil society, and the EU, who shape the climate and energy policies of Bulgaria; and second, an extensive review of government documents, financial reports, media coverage, and relevant databases to verify the information from the interviews as much as possible and substantiate the analysis.

Following the interviewing approach of Bogner, Littig, and Menz (2009), the research questions were first translated into an interview guideline, divided into five parts: (1) objectives and priorities, (2) actors, (3) policy content, (4) policy formulation, and (5) contextual issues. Context-specific questions were included based on ongoing debates concerning the energy sector and were varied by the type of actor interviewed (see online Appendix A.1 for interview guideline translated into English). Any information that can be linked to the subjects' identity was anonymized. 
Relevant interview partners were identified based on a detailed desk research and a preinterview with a local energy expert, which was also used to refine the interview guideline. The majority of the interviews, 13 out of 20 in total, were conducted in-person in Sofia over the course of January 2020 and had an average duration of 60 minutes. ${ }^{1}$ The remaining interviews were conducted in the months of February and April 2020 over the phone, due to limited availability (online Appendix A.2 provides a list of actors by type, organization, and date of the interview).

\section{Country context}

To better understand the underlying contextual factors influencing the coal regime in Bulgaria, this section provides a concise overview of the power sector and electricity sector in a historical perspective.

\section{Power sector overview}

Bulgaria has a well-developed power sector with a diverse energy mix consisting mainly of lignite-fired thermal power generation, nuclear and renewable energy. Lignite-fired thermal power plants (TPPs) provide, on average, nearly $40 \%$ of the electricity annually, while the country's only nuclear power plant (NPP Kozloduy) contributes another 36\% (Figure 3.1b). In addition to the strong baseload component comprising coal and nuclear, the country relies historically on a system of hydropower plants (HPPs), including three pumped-storage plants, that work in tandem with the baseload plants and cover peak demand. Under a preferential feed-in-tariff scheme, a rapid expansion of renewable energy sources (RES), including smaller hydro, wind, and solar power plants, took place between 2010 and 2012. This led Bulgaria to reach and exceed its 2020 RES target already in 2013 when the RES share in gross final energy consumption was 19\% - three percentage points higher than the 2020 target (Eurostat 2020b).

Coal is Bulgaria's only significant proven reserve of primary energy. Large deposits of low-grade lignite coal are found in the Maritsa East basin, located in the southeast of the country, along with smaller deposits in the southwest. Compared to the lignite coal mined in the rest of the EU, Bulgaria's is ranked among the lowest in terms of calorific values (Alves Dias et al. 2018). With the exception of lignite coal, Bulgaria imports almost all other energy carriers (crude oil, natural gas, and nuclear fuel) from a single trading partner - the Russian Federation (EC 2017).

Despite having reduced its greenhouse gas emissions (GHG) already in the 1990s, as a result of the structural change of the postcommunist economy, Bulgaria is the most resource, energy, and GHG emission-intensive economy in the EU. The national economy needs 3.8 times more energy and produces 4.4 times more carbon emissions per unit of GDP than the EU average (EC 2020b). Nearly half of the national GHG emissions in 2017 came from the 
(a). Gross Electricity Generation by Fuel$$
1990-2018
$$

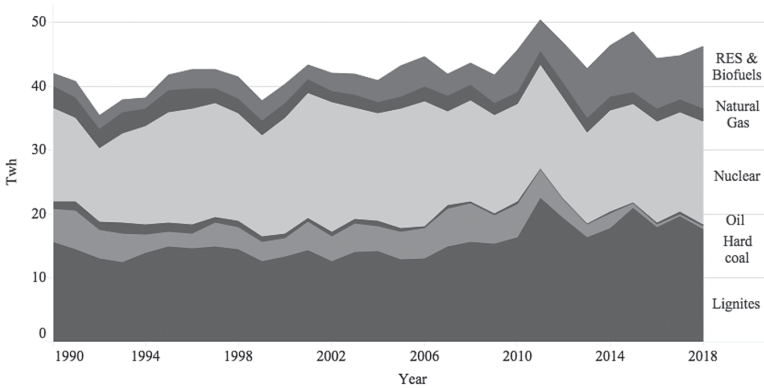

(c). GHG Emissions by Selected Sectors (excluding LULUCF) $1990-2017$

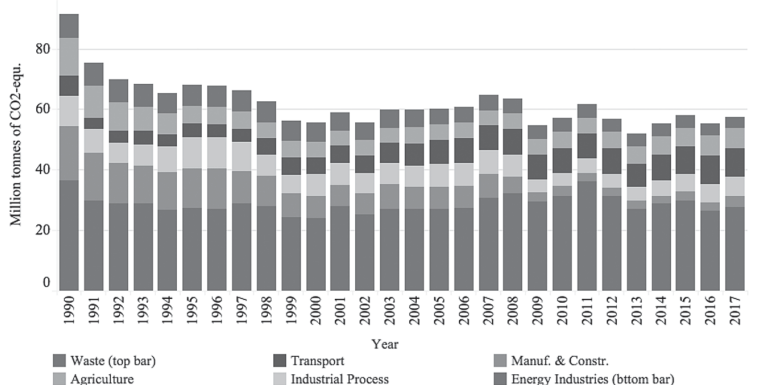

(b). Gross Electricity Generation by Power Plant Type

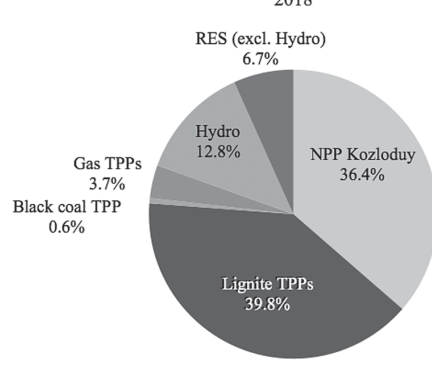

(d). Greenhouse Gas Emissions (excluding LULUCF)

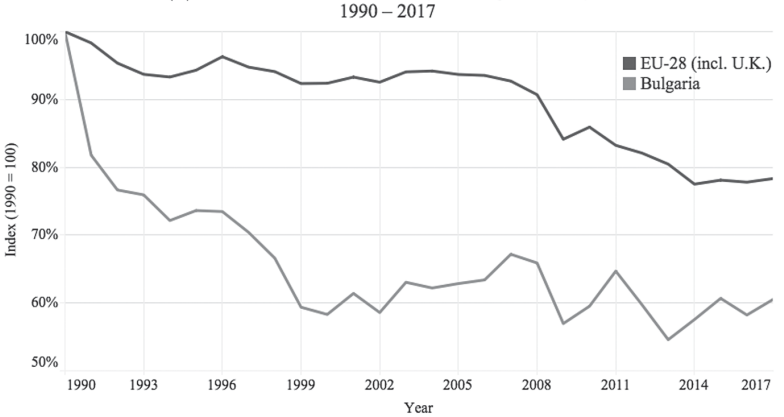

Figure 3.1 Key power sector statistics.

Note: (a) Gross electricity generation by fuel over time. (b) Gross electricity generation by power plant type in 2018 . (c) GHG emissions by sector (excl. LULUCF) over time. (d) GHG Emissions Trends (excl. LULUCF; Index $1990=100$ ). Source: Author's representation based on data for (a), (c), (d) from DG Energy (2020) and for (b) from EWRC (2019). 
energy sector with the production of electricity and heat from coal accounting for more than $90 \%$ of the emissions (MoE and MoEW 2020).

Bulgaria has a network of thermal-based power plants throughout its territory (Figure 3.2), including in most major cities where they supply district heating. Built mostly in the 1950s and 1960s, the majority of the plants are coalfired with some having switched to natural gas later on. There are 38 power generation units in 11 coal-fired power plants with an average age of 39 years (EC 2020b).

The Maritsa East Energy Complex hosts the largest lignite mining and lignite-fired power plant area in southeast Europe. The Complex features three of Bulgaria's biggest TPPs, as well as a fourth, smaller, one. The mines and the power plants are interdependent, as the output from the mines is almost entirely sold to the power plants. All mines are part of the state-owned Mini Maritsa East, along with TPP Maritsa East 2, which is the biggest power plant in the Complex in terms of capacity. The rest of the plants are majority privatelyowned with two being foreign-owned. In terms of employment, the Complex concentrates approximately $85 \%$ of all jobs in the Bulgarian coal sector.

Notably, the state-owned TPP Maritsa East 2 employs close to 2400 people, while the second biggest privately-owned TPP ContourGlobal employs only around 400 people (AOBE 2020). Most of the employees in the Complex come from the nearby city of Stara Zagora, which is the sixth biggest city in Bulgaria and its economy is heavily reliant on the activities of the Complex.

\section{Electricity market structure and governance}

The electricity market in Bulgaria is the only one in the EU to consist of both a regulated segment and a free market one, where prices are defined along the entire chain (see Figure 3.3). Since Bulgaria's accession to the EU, prices have been gradually liberalized for industrial and business consumers, while prices for households continue to be set by the formally independent Energy and Water Regulatory Commission (EWRC).

In the regulated segment, electricity prices are defined along the entire production chain to final consumption, with the state-owned National Electricity Company (NEC) acting as a public supplier. NEC procures electricity at prices determined by the EWRC (hereinafter the regulator), from generators it owns or through long-term power purchase agreements (PPAs) with privatelyowned generators and then sells the electricity to the end suppliers at fixed regulated prices. While the transmission network is owned and operated by a state-owned company, the distribution and supply of electricity is divided among three privately-owned companies, which have a regional monopoly. Bulgaria's household electricity prices have persistently been the lowest in the EU (Eurostat 2020c).

State-owned enterprises (SOEs) dominate the electricity market in Bulgaria. Collectively, they produce around $60 \%$ of the electricity in the country through a coal-fired, a nuclear, and a network of hydropower plants 


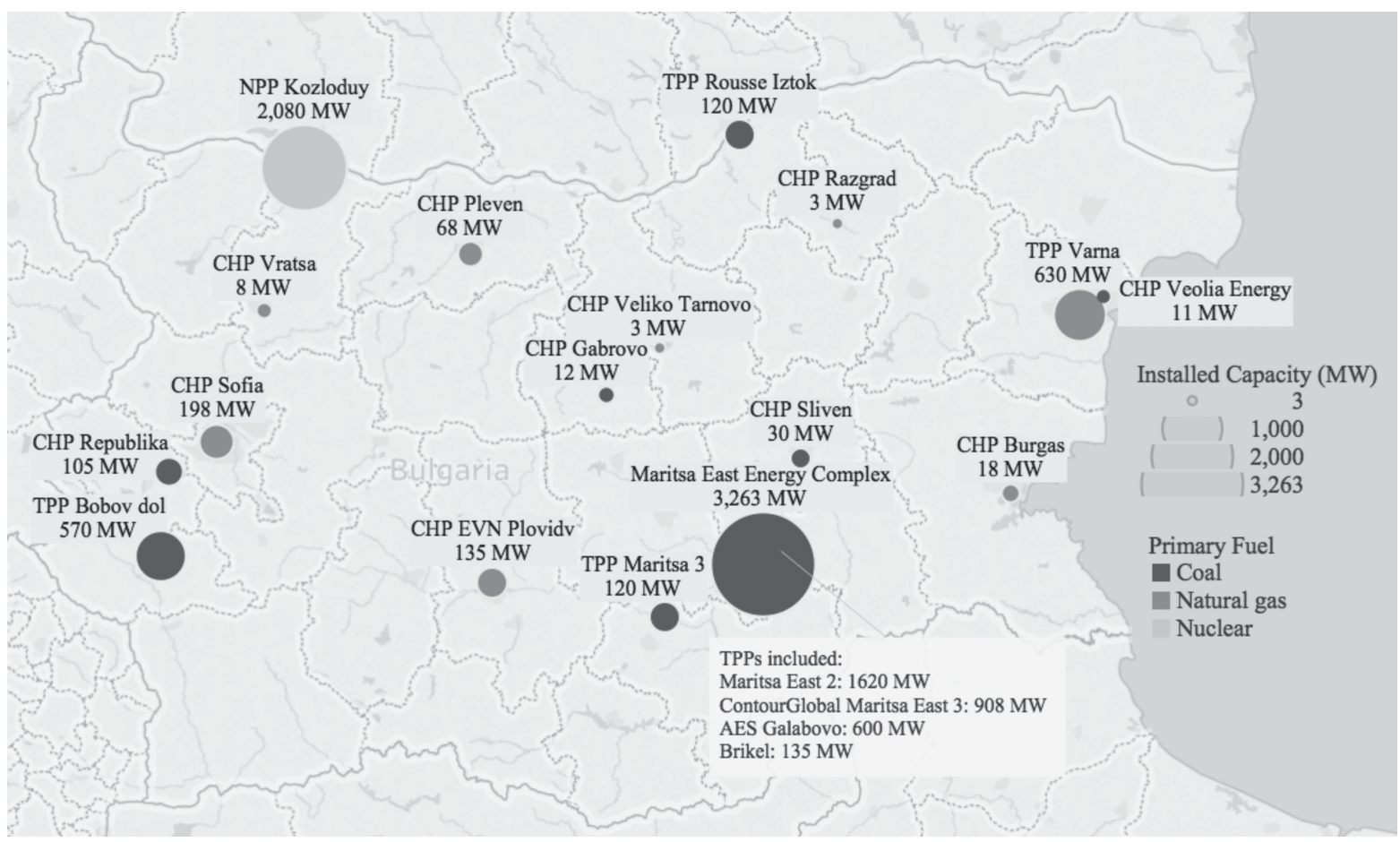

Figure 3.2 Map of thermal-based power plants.

Note: Fuel type (color) and installed capacity in MW (size of bubble). Map excludes auto-producer power plants.

Source: Author's representation based on data from Electricity System Operator, ESO (2020) and EEA (2019). 


\section{Toma Pavlov}

Table 3.1 Number of jobs in the Maritsa East Energy Complex

$\begin{array}{lr}\text { Mines } & 11300 \\ \text { Power plants } & 3200 \\ \text { Total direct jobs } & 14500 \\ \text { Total indirect jobs (e.g. transport, maintenance, supply chain, etc.) } & 29120\end{array}$

Source: Own calculations based on Vladimirov, Galev, and Primova (2020); AOBE (2020); TPP Maritsa East 2 (2019).

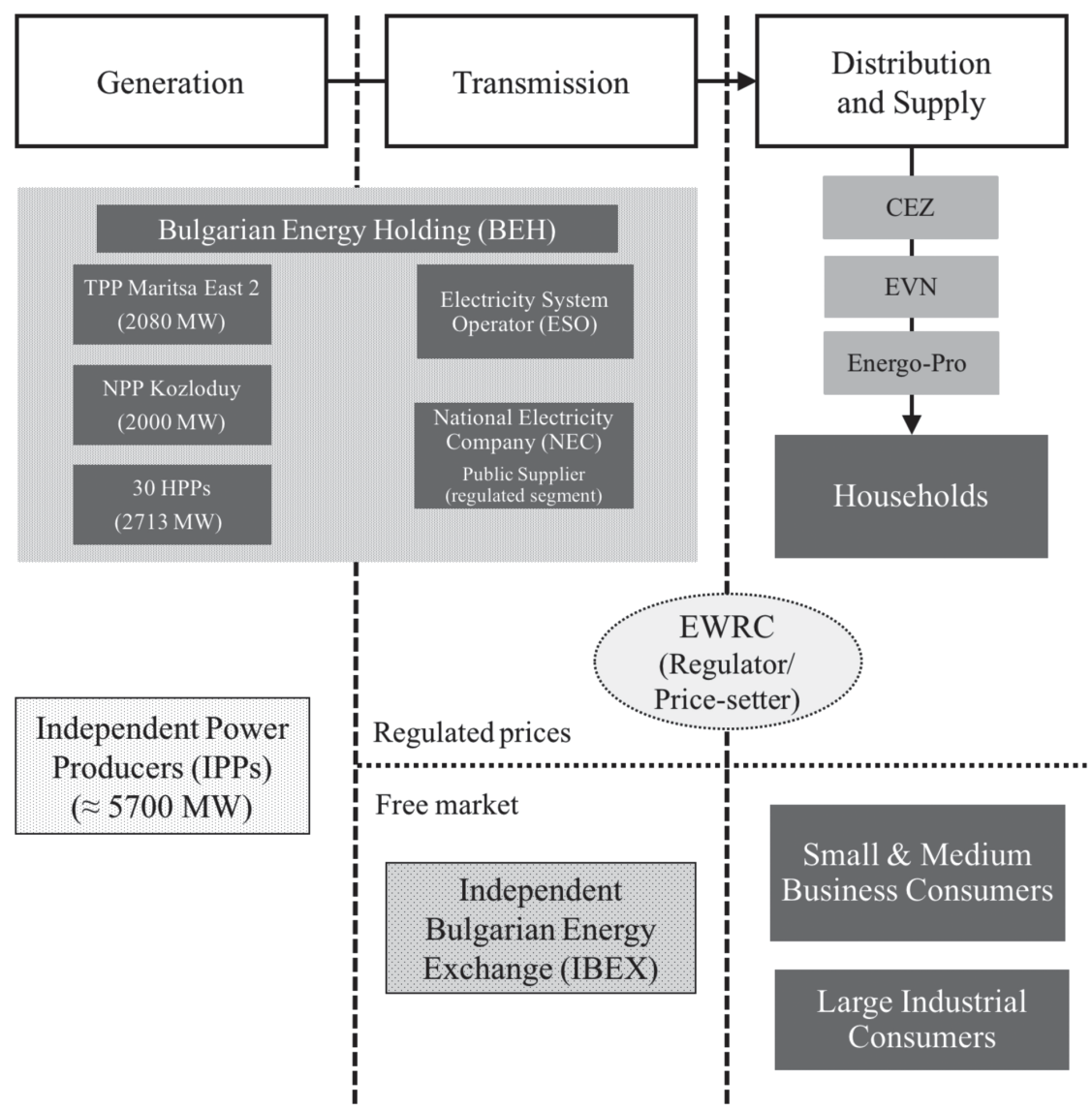

Figure 3.3 High-level structure of the Bulgarian electricity market.

Note:Amounts in MWs denote approximate installed capacity.

Source: Adapted from Ivanov (2019). 
(OECD 2019). All of the SOEs in the energy sector are part of the Bulgarian Energy Holding $(\mathrm{BEH})$, which is entirely owned by the state through the Ministry of Energy (MoE). With its subsidiaries, BEH engages in electricity generation, supply, and transmission, coal mining, as well as natural gas transmission, supply and storage.

Among the few large private electricity (and district heating) producers, two names stand out prominently - Hristo Kovachki and Ahmed Dogan. Formally a consultant, Kovachki is linked to some of the mafia figures from the 1990s and today his name is associated with 10 power and district heating plants across the country (U.S. Embassy Sofia 2006; Greenpeace 2018). Ahmed Dogan, is the former chairman of Bulgaria's third-largest party, Movement for Rights and Freedoms, and while no longer in active politics remains an influential political figure in the country. In 2018, Dogan became a majority-owner of TPP Varna. The sale of the TPP has been under an investigation by the Czech authorities because of potential underselling by the energy utility CEZ Electro Bulgaria AD (CEZ), which is majority-owned by the Czech state (ACF 2021).

\section{Political economy determinants of coal use}

Based on the analysis of the interviews and the extensive secondary research, this section outlines the political economy determinants of the coal regime in Bulgaria. The analysis is organized along the four general objectives for the energy sector identified through the interviews: (1) security of supply, (2) affordability of electricity prices, (3) promotion of domestic energy industry and local actors, and (4) alignment with EU policies. The coal regime has an influence on all four objectives, as it facilitates some, such as the security of supply, while it impedes others, such as alignment with EU policies.

\section{Security of supply}

Almost all actors identified the security of supply as the single most important objective for the energy sector [s1, p6, p7, s8, p9, s11, p12, b13, p14, s18, b19, s20]. ${ }^{2}$ This is mostly driven by the lack of other proven significant reserves of primary energy, except lignite coal, and the path-dependence in policymaking that relies on established sources of energy. Historically, lignite coal has played a significant role in Bulgaria's electricity mix and is thus perceived by most governmental actors as the best-known, most reliable, and locally available energy source that can guarantee the security of supply. Several actors singled out the January 2009 Russia-Ukraine gas dispute as the external event that strengthened the importance of coal the most. Due to Bulgaria's near full dependence on Russian gas supplies via a single route, Bulgaria was one of the worst affected countries when Russia cut off its supplies over the Soyuz pipeline. The government had to ask industrial facilities to stop production, while several gas-fired district heating plants were forced to switch to low-quality oil in order to maintain the heating supply (Kovacevic 2009). 
The expansion of the coal regime in Bulgaria was last promoted in 2001 when the then government signed long-term PPAs with two foreign investors for 23 and 25 years, respectively. Consequentially, a new 600 MW TPP (AES Galabovo) went into operation in 2011 in the Maritsa East Energy Complex, representing the first (and so far the only) large power plant built in the country after 1989. In addition, after a major refurbishment and life extension, the 908 MW TPP ContourGlobal Maritsa East 3 reentered into operation in 2009 under a $73 \%$ foreign ownership and with the remainder being state-owned. Jointly, the two power plants produce about $20 \%$ of the total electricity in the country and their output goes entirely to the regulated segment of the market. According to several actors, the main event that contributed to the expansion of coal capacities was the decommissioning of four nuclear units in the early 2000s, as part of an EU pre-accession agreement [p7, p9, p10, b16, b19]. The government considered lignite-fired TPPs as a viable baseload alternative that can also spur economic development in the Stara Zagora region. Furthermore, the large amount of free emission allowances that Bulgaria received under Phase II (2008-2012) of the EU ETS also made coal economically viable (Staykov 2020).

\section{Affordable electricity prices}

The artificially low prices of the electricity for households was one of the most commonly mentioned issues in the energy sector and was brought up by all types of actors [s1, p7, p10, p14, p15, b19, s20]. According to governmental actors, most citizens (and hence the electorate) perceive the state as having a social obligation to provide affordable electricity. Despite the seemingly low electricity prices, in a 2018 survey, 30\% of Bulgarian households said they were unable to pay their utility bills on time - the second-highest rate in the EU (Eurostat 2020a).

According to societal actors, prices for households are kept artificially low, in order to achieve certain political objectives [s1, s8, s11, p15, s20]. In 2013, mass protests brought down the ruling government, partially because of an estimated $20 \%$ spike in electricity bills, due to a mismanaged feed-in tariff (FiT) scheme for renewables (Kantchev 2013). Political decision makers have since become warier of the public opinion on energy prices, especially prior to elections. However, instead of protecting only the most vulnerable household consumers by creating an adequate compensation scheme, the authorities suppress prices for all households through the regulated market segment. According to one governmental actor [p14], Bulgaria still does not have a strategy on tackling energy poverty because responsible parties perceive it as a "thankless job," requiring a comprehensive assessment. ${ }^{3}$

The affordability objective is closely interlinked to the full market liberalization, which has been continuously delayed since 2013 and now should be completed by 2025 in line with relevant EU rules (Gocheva 2020a). The impact of below-market-rate prices is evident in the indebted utilities sector 
that systematically fails to generate profits. In 2018, the public supplier NEC was spending, on average, $92 € / M W h$ for purchasing electricity, while the regulator set the household electricity price to $37 € / \mathrm{MWh}$ (Stanchev 2019a). While part of the price difference is covered by a designated Electricity System Security Fund, which all final consumers on the free market pay through the so-called obligation to society fee, this is still not sufficient for NEC to recover its full costs. In the coal industry, regulated prices are not an impediment per se. For the two foreign-owned TPPs, the electricity prices do not matter, given their long-term PPAs with the government. Other coal-fired power plants are usually not included as suppliers to the regulated segment, due to the availability of cheaper generators. The exception is the state-owned TPP Maritsa East 2, which secures a market for at least some of its output through a preferential tariff it gets for supplying electricity to the regulated segment (see the next section). The plant can hardly compete on the power exchange where the average electricity price on the intraday and bilateral markets was around $48 €$ / MWh in 2019 (IBEX 2020). Only the variable costs of the TPP were as much, and when the fixed ones were added they rose to nearly $75 € / \mathrm{MWh}$ (EWRC 2019; TPP Maritsa East 2 2020a). This makes the regulated segment vital for the existence of the state-owned TPP.

\section{Support for domestic energy industry and local actors}

While not an explicit objective for the energy sector, direct and indirect subsidies are central to the coal regime in Bulgaria and were highlighted as such by all types of actors [s1, p10, p12, p15, s17, s18, b19, s20]. Formally, governmental actors justify the financial support with the need to ensure the security of supply. Politically, subsidies have a clientelistic role that ensures electoral support for the incumbent government, while preventing workers' protests from the otherwise bankrupt state-owned TPP Maritsa East 2.

Based on the interviews and the analysis of documents, four forms of coal subsidies emerge: long-term PPAs with the two majority foreign-owned power plants in the Maritsa East Complex, payments and intracompany loans to the state-owned TPP Maritsa East 2, high-efficiency payments for combined heat and power (CHP) plants, and the so-called "cold reserve" capacity payments. In total, subsidies amount to over $€ 450$ million per annum and have been significantly rising with the increase in the price of emission allowances (Vladimirov, Galev, and Primova 2020). ${ }^{4}$ Officially, the Bulgarian government states that it does not grant any fossil fuel subsidies or state aid (MoE and MoEW 2020). With the exception of the two PPAs, the decisions regarding the distribution and amounts of subsidies are rarely transparent. As one business actor [b19] put it: "The only thing that becomes known is who the winner is."

A broad variety of support measures are directed toward the financially distressed and state-owned TPP Maritsa East 2 [s1, p12, s17, b19, s20]. The first is a preferential tariff for supplying electricity to the regulated segment through a production quota determined by the Minister of Energy. Formally, 
the justification is an exceptional provision in the Energy Act, allowing the Minister to determine such quota for reasons of "reliability of the supply" (MoE 2003). The TPP can hardly compete on the power exchange and is operating, on average, at $25-35 \%$ of its maximum capacity, making the quota a vital source of revenues (TPP Maritsa East 2 2020a). As a subsidiary to BEH, TPP Maritsa East 2 also benefits from cross-subsidization, whereby the parent company shifts capital from better-performing SOEs to the financially distressed TPP in the form of intercompany loans [s1, p12, b16, s17, s18, b19, s20]. Under the scheme, BEH paid nearly $€ 158$ million for the emission allowances of the TPP in 2019 alone, which were later written as liabilities on the balance sheets, saving the TPP from being legally insolvent (Gocheva 2020c; TPP Maritsa East 2 2020a). Even with preferential tariffs and cross-subsidization, TPP Maritsa East 2 is still incurring losses and requires capital injections from the fiscal budget. In an unprecedented vote in January 2020, the opposition and the ruling party in the National Assembly passed a decision that obliged the government to take all necessary measures to prevent the closure of the state-owned plant, "regardless of the opinion of the European Commission on this issue" (National Assembly 2020). To fulfill this, the parent company BEH increased the plant's capital by over $€ 300$ million, provoking sharp criticism by both industry associations and environmental NGOs, who sent a complaint to the European Commission (EC) on the grounds of illegal state aid provision (Gocheva 2020b).

\section{Alignment with EU policies}

Alongside domestic actors, the EU plays a major role in the politics and society of Bulgaria, including in the energy sector. However, as the following subsections reveal, while domestic decision makers support the EU's decarbonization policies in words and on paper, they show resistance to their full implementation, creating bottlenecks, as well as backdoors to potential policy reversals.

\section{Decarbonization of the energy sector}

In the context of the energy sector, most actors perceive the EU as the main (external) driver of policy change [s4, p5, p6, s8, p9, p10, s11, p14, p15, s17, s18, b19, s20]. While societal actors consider the EU's influence as mostly constructive and positive, governmental ones are far more critical, especially of the EU's 2050 carbon-neutrality goal. Governmental actors raised the issue of the distributional costs of decarbonization for poorer states that also are heavily reliant on coal as their primary source of energy. What has become crucial for domestic decision makers is having a sufficient level of funding from the EU, which traditionally plays a major role in public financing and is also a vital source of political capital and rents. This way domestic decision makers can be sure that the political and social costs of a coal phase-out would not be excessively high. As one legislative actor [p10] said: "The stick is there, but the carrot is too small, especially for countries like ours." 
The discourse about decarbonization in Bulgaria was almost nonexistent in the political debate until the end of 2019. Occasional reassuring statements by the Minister of Energy that the country has enough lignite coal for 60 more years and the government plans to continue relying on it effectively suppressed a public discourse from emerging (BGNES 2019). At the same time, citizen awareness on decarbonization is assumed to be low, as most people are primarily concerned with the prices of energy, rather than where it comes from.

\section{National Energy and Climate Plan (NECP)}

The exact plans of the government about the phase-out of coal are unclear. There is no designated coal phase-out or "just transition" strategy, let alone a timeline for when power plants will be decommissioned. Bulgaria's NECP for the 2021-2030 period gives first implicit indications that a coal phase-out is coming but without any details around it. ${ }^{5}$ The NECP and its implications for the coal regime were discussed at length with all but three actors. Eight of them had participated in providing comments to the draft version or in the actual writing of the draft and final versions of the document.

The NECP was first presented in December 2019 and was made available in full to the public in February 2020 with its main authors being the MoE and the Ministry of Environment and Water (MoEW). Coal phase-out is not mentioned in the document, instead reiterating repeatedly that Bulgaria "plans to make full use of the existing potential of indigenous coal, which is sufficient to generate electricity for the next 60 years" (MoE and MoEW 2020, p. 25 , p. 148 , p. 209). With no further details on how this potential would be utilized, the actual projections on the development of the energy system show a diametrically opposing vision for the future of coal (see Figure 3.4).

The projections of gross electricity generation included in a separate annex document to the NECP show that a coal phase-out would start gradually after 2025 . In the 2026-2030 period, a 23\% reduction in the electricity generation from coal is expected, followed by another 50\% reduction in the 2031-2035 period. By 2040, coal will generate only a marginal amount of electricity, likely to cover periods of extreme peak demand. The first coal-fired power units are projected to go offline by 2025 when their installed capacity is expected to drop from the current $4.3 \mathrm{GW}$ to $3.4 \mathrm{GW}$. According to the projections, coal will be replaced primarily by expanding the role of nuclear power and natural gas, as well as renewables albeit to a lesser extent (see online Appendix A.3 for projected installed capacity by all main technologies).

The contradiction between the repeated identical statements on the future of coal and the energy system projections in the annex to the NECP is an illustration of the tension between the two competing political objectives of alignment with EU policies and legitimation/reelection. Having the two opposing messages on the future of coal, with one being more hidden and the other very prominent, gives political actors flexibility to use one or the other, depending on the setting (i.e., at home vs. in Brussels). The contradiction also 


\section{Projected Coal-based Electricity Generation $2020-2050$}

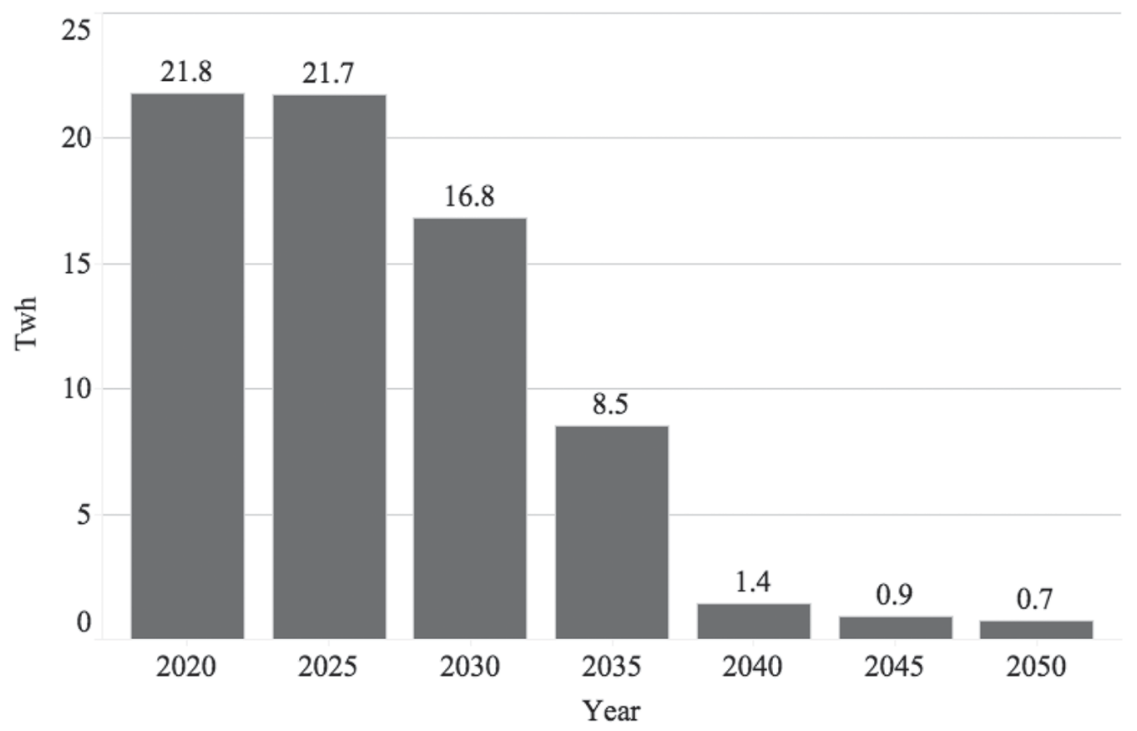

Figure 3.4 Projected Coal-based electricity generation (2020-2050).

Source: Author's representation based on data from annex document to the NECP (MoE 2020).

reveals the lack of consensus among domestic actors on the path the country would follow and discredits the NECP as a non-political document. This is evident also by the statements of public officials. When the NECP was presented by the Minister of Energy, she emphasized that the plan guarantees the long-term future of Bulgaria's coal-fired power plants until 2030 and only after that year a gradual phase-out will start, contradicting the projections (MoE and MoEW 2020). In a meeting with trade unions, the Minister was quoted as saying the year 2050 as a potential date for phasing out coal-fired power plants (KNSB 2020). Actors explain the continuous delay of a coal phase-out announcement with the government's fear of political backlash before key 2021 parliamentary elections [p7, p9, p10, p12, s17, b19, s20].

Trade unions were identified as the actor group with the highest bargaining power in the coal industry [s1, s2, s4, s8, p10, b14, p15, s17, s20]. Their large and concentrated membership base in the state-owned TPP Maritsa East 2 and in the mining company allows them to mobilize quickly and in large numbers. ${ }^{6}$ According to one union representative, 2035 is a "realistic and acceptable" phase-out year for the state-owned TPP Maritsa East 2. However, numerous other actors, including governmental ones, spoke of the scenario that the TPP 
becomes the first one to close in 2025 or prior, due to its poor financial state and the rising prices of emission allowances [p1, p10, p15, b19, s20]. Furthermore, from an economic perspective, the TPP is considered a low-hanging fruit, given that the plant is fully state-owned and is not part of a long-term PPA. However, from a political perspective, closing the state-owned TPP first would be far costlier, given the high staff numbers and the strong role of trade unions.

\section{EU mechanisms}

While domestic decision makers reassure coal communities that there is no deadline for the phase-out of coal, most actors expressed certainty that EU mechanisms will force at least some of Bulgaria's coal capacity to cease operations on economic and environmental grounds [p1, s4, p6, s8, p10, s11, p12, p14, s18, b19, s20].

Due to the increase in prices of emission allowances (from $€ 6$ per tonne/ $\mathrm{CO}_{2}$ in 2017 to $€ 15$ in 2018 and $€ 25$ and above in 2019 and 2020) and the significant drop in the amount of free allowances under the EU ETS Phase III, the variable costs of the coal-fired power plants have increased dramatically, making it harder for them to compete on the power exchange (IBEX 2020). Consequentially, the state-owned and biggest TPP, Maritsa East 2, has worked, on average, at 30-40\% and at 25\% of its total installed capacity in 2019 and 2020, respectively (TPP Maritsa East 2 2020b, p. 2). Despite the decreased utilization and increasing costs, the TPP maintained a workforce of nearly 2 400 people and allocated nearly €2.8 million of its 2019 budget to the sponsorship of a local football club (TPP Maritsa East 2 2019; Popova 2019). By contrast, several of the privately-owned plants linked to Hristo Kovachki have tried switching to refuse-dervived and biomass fuels in an effort to reduce their carbon emissions (Stanchev 2019b).

Further, the 2019 Regulation on the internal market for electricity was identified by actors as the mechanism of most serious future concern [s1, p6, p14, b19, s20]. According to the Regulation, from 1st of July 2025 onward, all of Bulgaria's existing fossil-fuelled power plants that emit more than 550 grams of $\mathrm{CO}_{2} / \mathrm{kWh}$ would no longer be eligible to receive subsidies to remain on standby in case of peak demand for electricity (European Parliament 2019). In the interim time, authorities can still make such payments but only after receiving permission from the EC and organizing an auction-based capacity allocation mechanism. ${ }^{7}$ According to governmental and societal actors, none of Bulgaria's coal-fired power plants can meet the 550-gram threshold without carbon capture and storage technology [s8, p14, s20].

\section{Discussion and conclusion}

The analysis of the four main objectives for the energy sector showed that three of them reinforce the coal regime. Viewed by political decision makers as the 
only reliable and locally available primary source of energy, coal plays a critical role in guaranteeing the security of the energy supply. In addition, the regulated segment has been an enabler for the state-owned TPP Maritsa East 2 to secure a market for at least some of its output. Furthermore, the synergy between the affordability and security of supply dimensions has been used as justification for the subsidies schemes that have given rise to clientelism in the state-owned plant and mining company.

Behind the coal regime stands a strong core alliance of incumbent players which includes the state, political decision makers from both the opposition and ruling parties, trade unions, and influential private actors. Contextually, the double function of the $\mathrm{MoE}$ as a government institution in charge of energy sector governance, but also one exercising ownership rights over BEH and its coal assets are leading to extremely high degree of politicization of energy policy decisions. Government policies become guided by favoritism for the SOEs, which help maintain the strong role of the coal regime and impede the energy transition. The findings suggest that the only viable way for a policy change to occur is through external pressures. As other cases have shown, regime destabilization takes place when more and more external pressures align (Brauers, Herpich, and Oei 2018; Leipprand and Flachsland 2018).

The biggest external pressure comes from the EU's decarbonization policies. While domestic decision makers have been shielding the coal industry from the negative impacts of more stringent EU standards by obtaining derogations or channeling subsidies, these are only short-term measures. The increasing price of emission allowances and the lack of staff optimization have already led to soaring economic losses and low utilization of the stateowned TPP Maritsa East 2, making it harder to justify the ever-increasing subsides without any reforms. Furthermore, the EU regulation on the internal market for electricity would make coal-fired power plants no longer eligible to receive payments for being on standby in case of peak demand after 2025. By the same year, plants would also become fully exposed to the free market competition, as the regulated segment gives way to the full market liberalization.

For domestic decision makers, the EU's carbon neutrality goal presents a difficult balancing act. On the one hand, adopting and implementing relevant EU policies is a high-level political priority. On the other hand, catering to the demands of the electorate for secure employment and affordable electricity prices translate to continuous delay and partial policy implementation. However, the delay of structural reforms could have high social costs, jeopardizing the "just" aspect of the impending transition. A viable way out for domestic decision makers is to have access to more EU funds that can be used as a reassurance to the electorate, but also likely as rents for firms close to the incumbent government.

The high allocation of funds to Bulgaria under the EU's 2021-2027 budget, combined with the market pressure on coal, has led to a notable change and Bulgaria has started preparing for the coal phase-out albeit without a defined 
timeline. While the government still has not announced any coal phase-out plans, territorial just transition plans on the regional level have been in preparation since the beginning of 2021. The plans are required by the European Commission to unlock funding from the EU's dedicated Just Transition Fund. In that process, even trade unions have started suggesting ideas, including the construction of an industrial solar photovoltaic plant on the premises of decommissioned mines with the participation and share ownership by former coal workers. Thus, despite all odds, Bulgarian coal regions have received a chance to plan more adequately their post-coal future.

\section{Acknowledgments}

I would like to thank all interviewees, who remain anonymous in this study, for taking the time to share their knowledge and opinions on the energy sector and the coal regime in Bulgaria.

I am very grateful to Prof. Dr. Christian Flachsland for his constructive feedback since the very inception of this study. I would also like to thank those who agreed to review the manuscript for their helpful comments and suggestions, including Dr. Michael Jakob, Dr. Jan Steckel, and Lorenzo Montrone from the Mercator Research Institute on Global Commons and Climate Change, Alexander Reitzenstein (E3G), Aron Buzogány (University of Natural Resources and Life Sciences), and Aleksander Sniegocki (WiseEuropa).

\section{Appendix}

This chapter contains supplementary online material at www.mcc-berlin.net/ pecoal/ch03.

\section{Notes}

1 A representative of one of the biggest foreign-owned coal-fired power plants in Bulgaria provided a written response instead.

2 To anonymize the identities of the interviewees, each interview session was assigned a number from 1 to 20 using Google's random number generator. The letter preceding the number refers to the actor type ( $\mathrm{s}$ - social; $\mathrm{p}$ - political; $\mathrm{b}$ - business). The cited numbers for the interviews do not correspond to the order in which the interviews are listed in online Appendix A.2, so that statements cannot be linked back to a specific interviewee.

3 As part of Directive 2019/944 on the internal market for electricity, the Bulgarian authorities have indicated that a mechanism for the protection of vulnerable electricity customers will be put in place by 2025 when the full market electricity liberalization should be completed (EC 2020b).

4 The figure includes only reoccurring transfers and not one-time-only transfers, such as capital injections and ministerial decrees.

5 The plan is required by the EC from all Member States to ensure the EU meets its energy and climate 2030 targets (EC 2020a). 
6 Throughout the years, protests and threats for such by coal miners and workers have been a way to keep the government in check and ensure its continued financial support for the SOEs (Nova, 2020).

7 As of May 2021, Bulgaria is still in discussions with the EC over the new capacity mechanism.

\section{References}

ACF. (2021). Czech Supreme Prosecutor's Office launches investigation into the sale of Varna TPP to Ahmed Dogan. ACF (blog), January 29. https://acf.bg/en/ cheshkata-varhovna-prokuratura-zapochv

Alves Dias, P., Kanellopoulos, K., Medarac, H., Kapetaki, Zoi, Miranda-Barbosa, E., \& Shortall, R. (2018). EU coal regions: Opportunities and challenges ahead. Text. Retrieved from https://ec.europa.eu/jrc/en/publication/eur-scientific-andtechnical-research-reports/eu-coal-regions-opportunities-and-challenges-ahead

Andreas, J., Burns, C., \& Touza, J. (2018). Overcoming energy injustice? Bulgaria's renewable energy transition in times of crisis. Energy Research and Social Science, 42(August), 44-52. doi:10.1016/j.erss.2018.02.020

AOBЕ. (2020). Писмо до премиера Бойко Борисов с позиция на АОБР относно решение на НС за ТЕЦ “Марица Изток 2" [Letter to PM Boyko Borissov with a position of AOBE concerning the decision of the National Assembly on TPP Maritsa East 2]. АОБР. Retrieved from https://tinyurl.com/y7zvt38t

BGNES. (2019). Теменужка Петкова: България ще продължи да ползва Въглищни Централи [Temenuzhka Petkova: Bulgaria will continue using coal-fired power plants]. Bgnes. Retrieved from https://tinyurl.com/ybhly7at

Bogner, A., Littig, B., \& Menz,W. (Eds.). (2009). Interviewing experts. In ECPR research methods. Palgrave Macmillan UK. doi:10.1057/9780230244276

Brauers, H., Herpich, P., \& Oei, P.-Y. (2018). The transformation of the German coal sector from 1950 to 2017: An historical overview. In C. von Hirschhausen, C. Gerbaulet, C. Kemfert, C. Lorenz \& P.-Y. Oei (Eds.), Energiewende 'Made in Germany': Low carbon electricity sector reform in the European context (pp. 45-78). Cham, Germany: Springer International Publishing. doi:10.1007/978-3-319-95126-3_3

Brauers, H., \& Oei, P.-Y. (2019). The political economy of coal in Poland: Drivers and hurdles for a shift away from fossil fuels.

Couture,T. D., Pavlov,T., \& Stoyanova,T. (2021). Scaling-up distributed solar PV in Bulgaria. Berlin: E3 Analytics. Retrieved from www.e3analytics.eu/

CSD. (2017). Policy brief no. 70: A road map for the development of the Bulgarian electricity sector within the EU until 2050: Focus on fundamentals. Retrieved from http://old.csd. bg/artShow.php?id=18060

- (2018). Policy brief no. 79: Decentralisation and democratisation of the Bulgarian electricity sector: Bringing the country closer to the EU climate and energy core. Center for the Study of Democracy (CSD). Retrieved from http://old.csd.bg/artShow.php?id= 18291

Energy, D. G. (2020). EU energy statistical pocketbook and country datasheets. text. In DG energy. European Commission. Retrieved from https://ec.europa.eu/energy/ data-analysis/energy-statistical-pocketbook_en

European Commission. (2017). Energy union factsheet Bulgaria. Retrieved from https:// ec.europa.eu/commission/sites/beta-political/files/energy-union-factsheet-bulgaria_en.pdf 
(2020a). National energy and climate plans. In Energy (p. 2020). European Commission. Retrieved from https://ec.europa.eu/energy/topics/energy-strategy/ national-energy-climate-plans_en. Text.

- (2020b). 2020 European semester: Country report-Bulgaria. Retrieved from https://eur-lex.europa.eu/legal-content/EN/TXT/?qid=1584543810241\&uri= CELEX\%3A52020SC0501

European Council. (2019). European council conclusions. Retrieved from www.consilium. europa.eu/media/41768/12-euco-final-conclusions-en.pdf

European Parliament. (2019). Regulation (EU) 2019/943 of the European Parliament and of the council of 5 June 2019 on the internal market for electricity (text with EEA relevance.). Retrieved from http://data.europa.eu/eli/reg/2019/943/oj/eng

Electricity System Operator. (2020). Data provided over email by electricity system operator (ESO), 2020.

Eurostat. (2020a). Arrears on utility bills. Retrieved from https://ec.europa.eu/eurostat/ web/products-eurostat-news/-/DDN-20200120-1

- (2020b). Share of renewable energy in gross final energy consumption. Retrieved from https://ec.europa.eu/eurostat/web/products-datasets/-/t2020_31\&lang=en

- (2020c). Household energy prices in the EU increased compared with 2018. Retrieved from https://ec.europa.eu/eurostat/documents/2995521/10826603/8-07052020AP-EN.pdf/2c418ef5-7307-5217-43a6-4bd063bf7f44

EWRC. (2019). 2019 annual report to the European Commission. Bulgaria: Energy and Water Regulatory Commission (EWRC). Retrieved from www.dker.bg/uploads/ 2019/EWRC_Report_to_EC_2019_EN.pdf

European Environment Agency. (2019). Reported data on large combustion plants covered by the industrial emissions directive (2010/75/EU). European Environment Agency. Retrieved from www.eea.europa.eu/data-and-maps/data/lcp-9. data.

Gocheva, R. (2020a) [юли [Around 12\% of the business and 3100 households enter the free market of electricity on July 1]]. In Около 12\% от бизнеса и 3100 домакинства излизат на свободния пазар на ток от. Retrieved from www.capital.bg. Retrieved from www.capital.bg/biznes/energetika/2020/02/25/4033815_okolo_12_ot_ biznesa_i_3100_domakinstva_izlizat_na/, 1 .

. (2020b). БЕХ реши да увеличи с. In лв. капитала на ТЕЦ "Марииа-изток 2' [BEH decided to increase the capital of TPP Maritsa East 2 with BGN 597 million]." Retrieved from www.capital.bg/biznes/energetika/2020/03/04/4036500_beh_ reshi_da_uvelichi_s_597_mln_lv_kapitala_na_tec/, 597 млн.

. (2020c). Почти 1 Млрд. Лв. Іп Струва “Спасяването" на ТЕЦ "Марица-Изток 2' за три месей [nearly BGN 1 billion costs the "saving" of TPP Maritsa East 2 for three months]." Retrieved from www.capital.bg/biznes/energetika/2020/05/20/ 4069159_pochti_1_mlrd_lv_struva_spasiavaneto_na_tec/?fbclid=IwAR36EGGnk 5k62WPSYNJSNUVYoiCUal1z8qgieJirJzHvOueknJoHEx4Bt4Y

МоЕ (2020). Интегриран план в Областта на Енергетиката и климата на република България 2021-2030 [National Energy and climate plan (version with annex documents)]. Retrieved from www.me.government.bg/news/integriran-plan-v-oblasttana-energetikata-i-klimata-na-republika-balgariya-2021-2030-2823.html?p= eyJ0eXBlIjoidGhlbWVuZXdzIn0=

Greenpeace Bulgaria. (2018). The financial mines of Kovachki. Sofia: Greenpeace. Retrieved from www.greenpeace.org/static/planet4-bulgaria-stateless/2019/03/ db06f7e3-the-financial-mines_en_short.pdf 
Heilmann, F, Reitzenstein, A., \& Ámon, A. (2019). The political economy of the low carbon transition: Climate and energy snapshot: Bulgaria. www.e3g.org/publications/ the-political-economy-of-the-low-carbon-transition-climate-energy-bulgaria/

Hiteva, R., \& Maltby, T. (2017). Hitting the target but missing the point: Failing and succeeding in the Bulgarian Renewable Energy Sector. In A guide to EU renewable energy policy. Retrieved from www.elgaronline.com/view/edcoll/9781783471553/ 9781783471553.00022.xml

IBEX. (2020). Monthly reports | Independent Bulgarian energy exchange. Retrieved from www.ibex.bg/en/about-us/reports/, 2020.

Ivanov, M. J. (2019). Governed by tensions: The introduction of renewable energies and their integration in the Bulgarian energy system (2006-2016), How history matters for the governance of sociotechnical transitions. Environmental Innovation and Societal Transitions, 32(September), 90-106. doi:10.1016/j.eist.2018.10.002

Jakob, M., Flachsland, C., Steckel, J. C., \& Urpelainen, J. (2020). Actors, objectives, context: A framework of the political economy of energy and climate policy applied to India, Indonesia, and Vietnam. Energy Research and Social Science, 70(December). doi:10.1016/j.erss.2020.101775

Kantchev, G. (2013). Protesting about power prices. The Economist. Retrieved from www. economist.com/eastern-approaches/2013/02/15/protesting-about-power-prices

KNSB. (2020). Пламен Димитров на срещза с министьр Теменужка Петкова: Три са Червените линии, които страната ни не може да премине при Зелената сделка [Plaтеп Dimitrov during a meeting with Temenuzhka Petkova: Three are the red lines, which our country cannot cross in accepting the green deal]. Retrieved from https://tinyurl.com/ y7dagw $3 f$

Kovacevic,A. (2009). The impact of the Russia-Ukraine gas crisis in south eastern Europe. Oxford Institute for Energy Studies. Retrieved from www.oxfordenergy.org/publications/ the-impact-of-the-russia-ukraine-gas-crisis-in-south-eastern-europe-2/

Leipprand,A., \& Flachsland, C. (2018). Regime destabilization in energy transitions:The German debate on the future of coal. Energy Research and Social Science, 40(June), 190-204. doi:10.1016/j.erss.2018.02.004

Lockwood, M., Mitchell, C., \& Hoggett, R. (2019). Unpacking "regime resistance" in low-carbon transitions: The case of the British capacity market. Energy Research and Social Science, 58(December). doi:10.1016/j.erss.2019.101278

Maritsa, Т. Р. Р. (2019). Финансов отчет кбм 31 декември 2019 г-ТЕЦ марица Изток2 [2019 financial report_-TPP Maritza East 2]. Retrieved from www.bgenh.com/ storage/app/public/uploads/files/finans/2019/31.12/FS-individual_TPP_2019_ BG.pdf. East, 2.

—. (2020а). Финансов отчет кбм 31 март 2020 г-ТЕЦ марииа Изток-2 [intermediate financial report till March 31 2020-TPP Maritza East 2]. Retrieved from www.capital.bg/getatt.php?filename $={ }_{\text {o_4 4063812.pdf }}$

- . (2020b). “'ТЕЦ Мариц̧а Изток 2' ЕАД - ТРР Maritsa East 2 Real Time Data.” Retrieved from www.tpp2.com/site/realTimeData.html

MoE. (2003). Energy Act. Retrieved from www.me.government.bg/en/library/ energy-act-256-c25-m258-1.html

MoE, and MoEW. (2020). National energy and climate plan of the Republic of Bulgaria, 20212030. Retrieved from https://ec.europa.eu/energy/sites/default/files/documents/ bg_final_necp_main_en.pdf

National Assembly. (2020). Народно събрание на република България-Решения [National Assembly decision]. Retrieved from https://parliament.bg/bg/desision/ID/157330 
Nova. (2020). Протести в защита на въглищата [Protests in defense of coal]. Nova.bg. Retrieved from https://tinyurl.com/y8ox8voy

Organization for Economic Co-Operation and Development. (2019). OECD review of the corporate governance of state-owned enterprises in Bulgaria. Retrieved from www.oecd. $\mathrm{org} /$ corporate/ca/Corporate-Governance-of-SOEs-in-Bulgaria.pdf

Peeva, V. (2020). Нова дотация за държавната ТЕЦ въпреки риск за глоба от EC [New subsidy for the state-owned TPP despite risk of fine by the EU]. Mediapool.bg. Retrieved from www.mediapool.bg/nova-dotatsiya-za-darzhavnata-tets-vaprekirisk-za-globa-ot-es-news303860.html

Popova, V. (2019). Поредното спасяване на ТЕЦ “Марица-изток 2” [Another saving of TPP Maritsa East 2]. Toest. Retrieved from https://toest.bg/maritsa-iztok-2/

Rentier, G., Lelieveldt, H., \& Kramer, G. J. (2019). Varieties of coal-fired power phase-out across Europe. Energy Policy, 132(September), 620-632. doi:10.1016/ j.enpol.2019.05.042

Stanchev, I. (2019а). НЕК отчита 74 Млн. Лв. Загуба и над 4 Млрд. Дългове [NEC Records a BGN 74 Mln. Loss and over BGN 4 Billion Debts]. Retrieved from www.capital.bg/ biznes/energetika/2019/05/06/3428908_nek_otchita_74_mln_lv_zaguba_i_nad_ 4_mlrd_lv_dulgove/

. (2019b). Ковачки цапа. всички му плащат [Kovachki pollutes, but everyone pays him]. Retrieved from www.capital.bg. Retrieved from www.capital.bg/politika_i_ ikonomika/bulgaria/2019/09/13/3962424_kovachki_capa_vsichki_mu_plashtat/

Staykov, K. (2020). Въглищзата-Държавен наръчник за влошаване на проблеми [CoalA state manual to worsen problems). Институт за пазарна икономика. Retrieved from https://ime.bg/bg/articles/vyglishtata-dyrjaven-narynik-za-vloshavane-naproblemi/?fbclid=IwAR2jHCgyeAHQjAJm2Jmuws2y4u6RgFl_IuII7N3iENawc 9HFABpi5a4rSqk

Stefanov, R., Galev, T., Vladimirov, M., Tsanov, M., \& Gantcheva, N. (2014). Sofia: CSD: Energy sector governance and energy (in)security in Bulgaria. Retrieved from http://old.csd.bg/artShow.php?id=16984

U. S. Embassy Sofia. (2006). Dirty energy: Corruption and lack of transparency plague Bulgarian energy sector. Sofia, Bulgaria: WikiLeaks Public Library of US Diplomacy. Retrieved from https://wikileaks.org/plusd/cables/06SOFIA1691_a.html. 06SO FIA1691_a.

Vladimirov, M., Galev, T., \& Primova, R. (2020). Accelerated lignite exit in Bulgaria, Romania and Greece: Chapter 3 (Bulgaria). Centre for the Study of Democracy (CSD). Retrieved from www.se3t.net/pdf/SEE-Coal-Exit_WEB.pdf

Vladimirov, M., Galev, T., \& Stefanov, R. (2019). Stifled decarbonisation: Assessing the Bulgarian national Energy and climate plan. Retrieved from https://csd.bg/ publications/publication/stifled-decarbonisation-assessing-the-bulgarian-nationalenergy-and-climate-plan/ 